Managing Workers' Capital? Limits and Contradictions of Labour Investment Funds

Ian Thomas MacDonald is Assistant Professor in the School of Industrial Relations at Université de Montréal. His research interests include labour organizing strategies, labour politics and radical political economy. His work has appeared in Labor Studies Journal, Socialist Register, and the British Journal of Industrial Relations. He is the editor of Unions and the City: Negotiating Urban Change (Cornell ILR Press, 2017).

Mathieu Dupuis: is Assistant professor in labor relations, TÉLUQ Montréal - University of Québec. He is conducting research on trade unions, comparative employment relations, multinational corporations, and the manufacturing sector. Recent publication: 2018. "Crafting alternatives to corporate restructuring: Politics, institutions and union power in France and Canada" European Journal of Industrial Relations, 24(1): 39-54.

\begin{abstract}
Labour-controlled investment is often touted as an alternative, pro-worker form of finance. Since 1983, the province of Québec in Canada has experimented with workers participation in the form of workers funds controlled by the two major trade union federations. Drawing on research from secondary sources, archival material and semi-structured interviews, this paper offers a comprehensive portrait of one of Québec main workers' funds, the FTQ Solidarity Fund. To date very little has been said about the impact of workers funds on firm governance, employment quality and labour relations. We argue that any attempt to use investment to shape firm behaviour in the interests of workers and local unions is a limited and contradictory project. The argument is sustained through a discussion of the historical formation and institutional practices of the Solidarity Fund. The presence of large union-controlled investment funds offers local firms an alternative source of capital investment, protecting small and medium-sized firms from more aggressive financial actors. However, our main results show persistent tensions and contradictions between the Fund's social goals and financial logics, as well as unintended effects on workplace union practices and power.
\end{abstract}

Keywords : capitalism; financialization; union pension funds, labour-management relations 


\section{Managing Workers' Capital? Limits and Contradictions of Labour Investment Funds}

Labour movements in North America having been debating whether to take an active role in the investment decisions of collectively bargained pension funds since at least the 1970s, when unions began to assert more control over jointly-managed pension boards. ${ }^{1}$ The question remains a salient one as public-sector pension funds in particular have grown in size and sophistication to become major actors in the restructuring of global capitalism, even as pension coverage continues to slide in the private sector and, more recently, in the public sector as well. As pensions became deregulated and invested in the booming stock markets of the late 1980s and 1990s, capital gains have at times exceeded contributions from plan beneficiaries and sponsors as pension funds have taken on the characteristics of investment banks or mutual funds seeking higher rates of return through riskier financial strategies (Archer, 2011). It was in this context of pension fund deregulation and financialization that union-bargained funds came to be thought of as 'workers' capital' - with the implication that this capital ought to be managed in a way that is at least consistent with the interests of plan beneficiaries insofar as they are wage earners and members of working class communities (Fung, Hebb and Rogers, 2001; Carmichael and Quarter, 2003).

It was not unreasonable in this context for trade unionists in the public sector especially to be concerned that union-bargained funds were being invested in ways that undermined employment quality and union bargaining power. This concern invites reflection on whether unionists should consider themselves responsible for the investment decisions of their pension funds and whether, through increased union control, workers' savings could be invested in such a way as to counter financialization, and even used in strategic ways to extend union power and 
improve working conditions. In short, can 'workers' capital' be managed in ways that are consistent with union principles and building union power?

The literature on 'managing workers capital' has suggested multiple ways by which union pension trustees might better align their fiduciary duty to plan beneficiaries, on the one hand, and the interests of workers, local communities and unions on the other. The most commonly discussed are social investment screens which deselect firms or sectors that do not meet labour, environmental or ethical standards, and shareholder activism, where labour shareholders vote on 'good corporate governance' criteria that align with shareholder interests at annual meetings (Clark and Hebb, 2004; Bauer, Koedijk and Otten, 2005; Coiquaud and Morisette, 2010). Another, more likely avenue would have union trustees use their influence over pension fund governance to shift capital markets away from purely speculative activities, such as leveraged buyouts that shed labour and undermine employment quality (Baker and Fung, 2001; Applebaum and Batt, 2014) or short term asset trading that bears little or no relationship to the real economy and employment creation. A more solidaristic avenue for managing workers' capital would have union-controlled funds used to leverage union power in the workplace by directing investment to unionized firms or heavily unionized sectors to sustain union labour markets, to protect union employment in cases of restructuring or to promote reindustrialization (Rifkin and Barber, 1978; Croce et al., 2011; McCarthy, 2017).

The 'workers' capital' perspective has argued that the limits to such strategies arise from shared control of pension funds, lack of knowledge and strategic direction given to union trustees (Weststar and Verma, 2007) and external rules imposed by the state, either through anti-union legislation (McCarthy, 2017) or unduly narrow interpretations of fiduciary duty found in AngloAmerican common law (Wessel, 1986; Webber, 2014). We do not dispute these limits. Union agency in the field of investment is constrained by externally-imposed institutions. However, 
institutionalist and actor-centered approaches to the 'workers capital' debate are overly optimistic about the potential of union interventions in the realm of finance, we argue, as a result of their failure to consider a more fundamental contradiction between union power, on the one hand, and the nature of capital, on the other, that necessarily accompanies labour's investment in capitalist firms. Investment funds, regardless of ownership or internal practices, must submit to the imperative to accumulate on the basis of profits extracted, ultimately, through control over a production process that is based on conflictual relations between firm owners and wage earners. Local unions contest this control and attempt to shift the distribution of firm revenues to their members. They do this by strengthening internal solidarity, contesting managerial discourse and promoting an independent framing, and developing broader alliances with communities and other unions (Lévesque and Murray, 2010). That there has been very little discussion of the relevance of this contradiction in the 'workers capital' debate is partly owing to the implicit theorization of capital as a resource rather than as a social relation of production. It is also the case that there are very few empirical examples of labour investment funds where contradictory roles - and not externally imposed institutional limits or weak strategic direction - represent the most salient restraint on using workers' savings to extend union power or improve working conditions.

This paper brings the contradictory nature of labour-controlled investment to the fore through a case study of Quebec's Solidarity Fund (FSFTQ). The Fund was sponsored and is still effectively controlled by the Fédération des Travailleurs et Travailleuses du Québec (FTQ), the Province's largest union federation with 35 national and international affiliated unions representing over 600,000 workers in the both private and public sectors. ${ }^{2}$ The founding legislation mandates the Fund with both a financial and a broad social mission. Fund investments must favour the protection and creation of employment in Quebec, promote the economic development of disadvantaged regions, advance workers' retirement security, and foster 
“economic knowledge among the workforce", all the while ensuring a reasonable rate of return. ${ }^{3}$ The Fund is given wide latitude in terms of how to accomplish these goals and benefits from generous tax incentives. With total assets of $\$ 13.7$ billion, including $\$ 8$ billion under active investment in Quebec enterprises, the Solidarity Fund represents the largest source of venture capital in Quebec (Fonds FTQ, 2017). To our knowledge, no other labour movement in the world has established such a degree of control over workers' savings and taken such a large share of the venture capital market in its jurisdiction.

The Solidarity Fund is unique in ways that make it a useful case from which to think about the limits and contradictions of managing workers' capital. While some external limits are imposed, the Solidarity Fund is least burdened by the legal constraints that prevent union trustees in other contexts from using workers' savings to improve the quality of employment and leverage union power. The Solidarity Fund is not constrained by employer preferences on jointly-managed pension boards and so the issue of shared control is removed as limit on labour fund investment decision making. The Fund differs from other experiments in "shared capitalism" (Kruse, Blasi and Park, 2010; Carberry, 2011) and Labour-Sponsored Investment Funds (LSIFs) in English Canada, in that Solidarity Fund investments are made by workers' representatives, and investments are accompanied by representation on the board of the firm. ${ }^{4}$ Further, the Fund is less constrained to maximize profit. Fund managers do not seek to maximize profits above all else $-\mathrm{a}$ 'decent' return will do. Given the substantial public subsidy involved, the Fund is in any case under much less pressure in this respect. Finally, the Fund acknowledges the contradictory nature of 'managing workers' capital' in the institutional practices that have been developed to manage these contradictions. The founders of the Fund and current management, as trade unionists, do not deny that there is a basic conflict between the interests of wage earners and profit-seeking shareholders. On the contrary, the Fund was designed to manage these contradictions as much as 
possible in the interests of workers, and a great deal of thought has gone into the question of what impact Fund investment will have on firm employees and local unions. If unions could use workers' savings strategically to improve working conditions and counter financialization, we would expect the Solidarity Fund to be a successful such case.

In emphasizing how even this most likely case of labour-controlled capital is constrained to behave like capital, rather than succeeding in bending the rules of capital to the needs of workers and unions, this paper casts some doubt on whether increased control over pension funds could serve the purposes of the labour movement. There have been few if any attempts to understand the internal practices of labour-investors and the Solidarity Fund in particular. Too often institutional practices which are presented as achieving 'social' or union goals are taken at face value, rather than seeking to understand how they were developed in response to the limits and contradictions of investment as a union tool. We begin with a critical review of the 'managing workers' capital' perspective, outlining where we see the limits and contradictions of this project, focusing on three approaches outlined above. We then turn to a historical account of the formation of the Solidarity Fund, situating the project in the highly constrained context of the capitalist crisis of the late 1970s/early 1980s and Quebec labour's accommodationist response to the neoliberal turn. This historical account makes clear that institutional innovations that have been interpreted as extending union control over firms and capital markets were on the contrary developed to keep union and financial logics as separate as possible. A third section discusses the Fund's investment decision-making process and questions how, concretely, affiliated unions and worker shareholders impose union and social rules on firms through this process. Our discussion of the institutional practices of the Solidarity Fund reveals their limited purchase on firm governance. Rather than extending union control over investment, these institutional practices were developed to manage the contradictions and liabilities of labour-controlled investment as we 
have theorized them in this paper and as the founders of the Solidarity Fund themselves understood them. The conflictual cases of Fund investment we refer to in this section are not intended to be representative of relations between the Fund and local unions and workers. Rather, in revealing latent sources of tension between two separate projets - local union power and union-controlled investment - they exemplify the limits and contradictions highlighted by our theoretical approach to 'managing workers capital' more generally. We conclude by drawing the implications of this case for debates on union control over pension funds.

The research is based on three sources. We were afforded privileged access to key informants, including the surviving founders of the Fund (2), current Fund staff, including directorships (3), former staff (1), and staff of affiliated unions who have engaged with Fund strategy and governance (2). Our Semi-directed interviews $(\mathrm{N}=8)$ lasting an average of 2 hours were conducted in 2016 and early 2017 and fully transcribed. These sources are not without their limitations. Although our interview subjects were frank in acknowledging the challenges and limits of their project, the interview strategy we employed has given us a view from the top and from the inside. However, given the nature of their work in managing the project on a daily basis, these sources provide a much more sober evaluation of the limits and contradictions of managing workers' capital than is found in much of the literature. We have also relied on publicly available data on the structure, operations and financial returns of the Fund as reported in the annual financial statements as well as grey literature produced by the Fund and by third parties. Interview material was cross-referenced in research conducted at the Solidarity Fund archives in the fall of 2017, including official policies of the FTQ, Congress reports, and the union federation' newspaper, Le monde ouvrier.

\section{Managing Workers Capital}


Three approaches to managing workers capital can be identified through which unioncontrolled funds could conceivably have a positive impact on firm-level labour relations and union power: empowering shareholders to be more engaged in corporate governance in a 'socially responsible' way; a passive investment strategy which provides 'patient capital' to firms, providing the credit required to hire workers to produce goods and services in the real economy; and a more active strategy in which ownership stakes are used to sustain collective bargaining or promote better employment practices by changing firm behaviour. The Solidarity Fund stakes its claim to be an alternative, pro-worker investment vehicle on the grounds that it favours the latter two approaches.

The limits and contradictions of the first approach should not detain us. ${ }^{5}$ Given that pension funds in general (let alone funds partly controlled by worker representatives) nearly always represent a minority of total company stock, and a small percentage of financial assets in the economy as a whole, shareholder activism as a means of improving the quality of work and labour relations is logically limited to cases where the interests between a firm's workforce and shareholders align, and shareholders are able to impose these interests on management. Even if costs associated with raised labour standards may be offset by lower reputational risk (Ghiralducci et al., 1997; Hebb, 2001; Carmichael, 2005), evidence that financial markets undervalue unionized firms (Abowd, 1989) and that unions reduce financial returns to shareholders (Becker and Olson, 1989) would suggest that any alignment between labour and shareholders could only be marginal and fortuitous. Unions are perceived by finance as competing for rents to be extracted from the firm and it is partly for this reason that the rise of finance has been associated with the decline of organized labour (Peters, 2011). 'Shareholder engagement' and 'good corporate governance', promoted in large part by pension funds in alliance with other institutional investors with a view to maximising profit and minimizing 
investor risk, is associated with lower employment standards and weaker labour power resources (Applebaum, Batt and Clark, 2013; Applebaum and Batt, 2014).

Moreover, this approach sits uncomfortably with basic principles of trade unionism shareholder activism is legitimated on the grounds that businesses are run in the interests of shareholders, and measures to enhance shareholder engagement are used in turn to legitimize the claims of shareholders to firm profits against those of workers (Stanford, 1999; Marens, 2004; Soederberg, 2009; Talbot, 2013). Relying on shareholder conventions and norms to regulate employment runs counter to organized labour's longstanding opposition to shareholder ideology and support for state regulation of financial markets (Jacoby, 2008).

The second approach - directing workers savings to long-term investments in the form of private equity or debt of non-financial firms - would seem to counter pressure from capital markets on firm management to maximize short term profits at the expense of secure employment or other social criteria. Comparative political economy has put great store in the complementarity of bank-based financial systems to higher levels of employment protection, employer autonomy, employee skill development and even local union power (Estevez-Abe, Iverson and Soskice, 2001; Hall and Soskice, 2001). The interest in counterposing 'patient' to 'impatient' capital arises from a concern that, with the decline of bank-based lending, institutional investors are systematically able to exert pressure on firm governance as a function of investment time horizon, and that this pressure, or lack of financial commitment, undermines the long term planning and the sharing of risk (Lazonick and O'Sullivan, 2000; Auvray et al., 2016). ${ }^{6}$

Often given normative connotations, the implications of patient capital for the quality of employment and labour relations would appear to be highly contingent on who controls the capital and what strategies they pursue (Naczyk, 2016). Union trustees might prefer to align their 
interests with industrial capital and commit capital to firms prepared to make long term investments in plant and the local workforce, or to make investment decisions based on an interest that plan beneficiaries may have in the viability of an economic sector or region (ibid.). If the interests of plan beneficiaries are understood to include maintaining area employment levels, then fiduciary duty might pose a less relevant limit on union trustees inclined to eschew profit maximisation in favour of local economic development (Webber, 2014).

Although this approach to managing workers capital comes closer than the first in directing resources to the real economy, and therefore is more likely to be associated with positive employment outcomes, patient capital strategies are ambiguously related to financialization. Patience has been used to rationalize profit against socialist critique since at least J.S. Mill's Principles of Political Economy (1848) and Frédéric Bastiat's Economic Harmonies (1850) and it is not incidental that Patience should be one of the Victorian virtues to re-emerge in the discourse of financial actors in the wake of the 2008 financial crisis. Furthermore, this focus on difference in the time horizon of varieties of financial capital continues to center financial actors as drivers of financialization when this may overstate the case. Knafo and Dutta (2016) trace the financialization of the firm to managerial innovations within the large conglomerates of the 1960s, rather than pressures emanating from financial markets, while it remains the case that most corporate investment is financed internally through retained earnings rather than through issuance of debt or new shares (Stanford, 1999).

For union pension trustees, patient capital investment has the potential of triggering a series of political liabilities for public sector unions in particular, as their pension funds seek out long term value orientations in private equity funds, real estate, and privatized state assets in the form of private-public partnerships (P3s) against which they have strongly campaigned (Calvert, 2005; Archer, 2011). Expanding private ownership models in public infrastructure, promoted by 
the financial industry with pension funds in the lead, is consistent with a deepening of financialization in the sense that new circuits of capital are being opened up in the public sector, including in heavily unionized health care, education and municipal services, where profits are to be made through outsourcing and non-union service delivery. Such patient capital strategies would be associated with worse rather than better work. More generally, making fine distinctions between patient and impatient capital implies taking a political position in favour of one type of asset class over another when the issue is the empowerment of financial capital as a whole.

The third and most promising approach would have union-directed investment used in a much more interventionist way to leverage union power by influencing firm decision making, the organization of the labour process and labour relations, and in supporting unionized firms or sectors that are highly unionized (Coiquaud and Morissette, 2010; Webber, 2018). In this vein, unions may use the board representation that ownership affords to block anti-union practices or smooth accreditation, or to pass on proprietary information to workers and bargaining committees. The latter course of action would empower workers by giving them a clearer picture of firm finances, and give local unions a firmer basis from which to offer alternative restructuring plans that privilege maintaining employment levels and bargaining relationships, with financing provided by labour's investment arm. This was the rationale behind the argument for using labour-investment funds to reindustrialize the US rustbelt in the late 1970s (Rifkin and Barber, 1978). There is a long history in the United States of the building trades and Teamsters using multi-employer pension funds to sustain employment growth in unionized firms, before TaftHartley and the Employee Retirement Income Security Act of 1974 made such practices more difficult if not impossible (Barber, 1982; McCarthy, 2014, 2017). McCarthy presents the Solidarity Fund as a counter-factual of a more solidaristic path to managing capital, a case of 
what might have been if political developments in the United States had not foreclosed the possibility (McCarthy, 2017: 121-124).

The managing workers' capital literature often assumes that union representation on the board of firms implies an intrusion of union or 'social' logics into capitalist logics. The reverse of the medal - the intrusion of market logics on union practice as unions take responsibility for firm profitability and survival - is rarely theorized or even recognized. It was precisely this refusal to take on management responsibilities that, until the late 1970s at least, explains why North American labour leaderships wanted no part in the investment decision making of union pension funds. "We would end up bargaining with ourselves, and we'd be forced to decide between our role as representatives of workers and representatives of owners" (cited in Barber, 1982: 42). The same dilemma challenges those who see the Solidarity Fund as a promising breach in capitalist control of investment. In his discussion of the Solidarity Fund as a case of "social capitalism as a pathway of social empowerment," Wright (2016: 161) nevertheless recognizes that the Fund's "investment strategy is to strengthen the competitiveness of firms within the Quebec economy, not to weaken Quebec capitalism, and to foster more collaborative relations between employers and workers through financial education and other devices, not to increase class antagonism" (Ibid). While we agree with his characterization of the Fund's investment strategy, Wright is begging the question of how a project of strengthening capitalism and firm-level competitiveness through partnership unionism is consistent with social empowerment over capital.

Neither union-controlled investment funds nor the firms in which they invest are exempt from the disciplines that market competition imposes on all actors under capitalism. If labourcontrolled investment funds are to maintain their share of the capital market, investments must return a rate of profit that is sufficient to reproduce the fund on an expanded scale. The firms in which the fund invests must earn a rate of profit sufficient to cover these returns as for any other 
investor. The average profit rate is socially-determined in the sense that it is externally imposed on individual firms through a competitive process by which more productive firms 'regulate' their competitors, forcing them to increase their own productivity on pain on being forced from the market. Employment levels, wages and work organization are all heavily determined by this need to organize the production process in such a way as to ensure an average rate of profit. It is this external competitive pressure which imposes on union-controlled capital the imperatives of capital, rather than the needs of workers.

Any number of social or pro-union practices can be demanded of firms in exchange for investment, but in competitive capital markets, firms are under no obligation to accept these terms. Any such imposition on the firm has either to be offset by a lower profit expectation or some other advantage. To the extent that union-controlled funds benefit from higher quality firmlevel information relative to other institutional investors (assuming they consult with workers before making an investment) they may be able to offer preferential terms that would overcome some of the liabilities, from a business perspective, of inviting a labour investor on to the board. Firms may in turn derive benefits from higher trust workplace relations if labour not only provides patient capital, but is furthermore engaged in organizing the collaboration of workers in high-performance practices that may be unworkable in low-trust workplaces dominated by financial market pressures. Laliberté (1997: 47) has mounted a defense of the public subsidies the Solidarity Fund receives on these grounds, that labour-investors allow small and medium-sized firms to overcome agency problems in the workplace and on capital markets. But this assumes that the Fund will encourage a partnership- and competitiveness-oriented unionism at the local workplace level, foregrounding again the needs of capital.

Firms facing bankruptcy may have little choice but to accept labour-controlled investment with various rules attached. If labour funds invest in such firms to protect employment and union 
recognition, they are nevertheless committed to participating in a restructuring process that is likely to involve concessions on wages and work rules. This outcome might be judged preferable to unemployment or union suppression, but it does involve a union-controlled institution impressing on workers the imperative of market competition and sacrifice. Firm owners may even welcome labour investors in such cases if this promises to smooth the acceptance of concessions on work rules, wages and retiree benefits. ${ }^{7}$ Rescuing bankrupt firms implies lower profits and higher risks. If labour-controlled investors are to maintain average returns, they must also invest in less risky, more profitable firms and sectors, regardless of employment or social considerations.

The same dilemma confronts attempts to use labour funds to defend employment in areas that have been abandoned by capital. Fixing capital in such areas has been interpreted in the literature as giving workers tools to counter deindustrialization and even the uneven development of capitalism (Lincoln, 2000). Again, labour-controlled investors must find themselves pulled in both directions, fixing capital in declining regions to meet social mandates while seeking out higher profit investments in dynamic sectors and more productive firms, heightening uneven development even as they take responsibility for the social and employment implications of this.

The contradictions identified above are all attenuated if labour-controled capital is subsidized by the state. Subsidized funds can grow and maintain market share with below average returns, freeing the fund to priviledge more 'social' or union-oriented criteria. But this only raises a further dilemma for labour, that of undermining the tax base to promote private capital accumulation (Gindin, 1988), and in becoming dependent on continued government support. ${ }^{8}$

\section{Managing capitalist crisis: the FTQ and the quest for full employment}


The notion of launching a Solidarity Fund was selected from a variety of possible labour responses to a deep economic crisis that shook Canada and Quebec particularly hard in the early 1980s. The Fund was intended as a response to this crisis in a period of political realignment within the labour movement. Throughout the 1970s, FTQ-affiliated unions in heavy industry and manufacturing had been calling on the labour central to do something about plant closures and mass layoffs (Le monde ouvrier, December 1983). The research department would intervene on a case-by-case basis but with few means at their disposal and nearly no influence on government policy and so to limited effect (interview subject \#3). With the election of the labour-backed social-democratic Parti Québécois (PQ) to power in 1976, a more corporatist approach to the employment crisis presented itself in the context of a series of 'socio-economic summits' that were convened between government, business and labour - the latter two henceforth referred to as 'socio-economic partners.' It was during the 1982 summit that, at the behest of the FTQ, the government launched a tri-partite housing development corporation (Corvée Habitation) intended to restart the residential housing sector with tax-subsidized financing from different levels of government, the banks and construction workers themselves. This was the model that the labour central wanted to scale-up and apply across the industrial economy: bring down the cost of capital in defined sectors with tax-incentivized retirement savings and thereby restart private investment and employment growth, all under a tri-partite governance structure (interview subject \#3).

Some of the largest FTQ affiliates at the time belonged to US-based Internationals. Members assisting annual International union conferences were well aware of the crisis besetting the US rustbelt and were open to solutions proposed by their US brothers and sisters. For instance, the Employee Share Ownership Plan (ESOP) model, increasingly popular in both unionized and non-unionized firms in the US, was considered but ultimately rejected on the 
grounds that workers should not risk investing their retirement savings in their place of employment in a period of rapid industrial restructuring. Universally committed to social democracy, the Quebec labour movement looked to Sweden for inspiration in policy innovation, and at the end of the 1970s the FTQ sent a delegation to study the Meidner wage earner funds (Le monde ouvrier, June 1979) - a much more assertive labour strategy to socialize capital ownership that proved beyond the reach even of the Swedish unions and was considered impractical in Quebec given its liberal political culture, and the much weaker position of organized labour within the state. ${ }^{9}$ Finally, business balked at a tri-partite fund for re-industrialization. The FTQ went so far as to propose agreeing to the government's planned 20 percent across the board public sector wage cuts if the savings were rolled into such a fund (interview subject \#3). This too was refused. Ultimately the FTQ went ahead with its own fund, based on voluntary taxincentivized contributions from workers. The central had wanted contributions to be levied at source from workers' pay packets, as with automatic union dues, but this was abandoned at the last hour over Liberal party opposition.

In this exercise in "pure innovation" (interview subject \#3), the labour movement could nevertheless draw on a culture of social entrepreneurship and cooperative finance rooted in the francophone Québécois small business community. The FTQ relied heavily on this milieu for expertise in starting up the fund, including assistance from a government agency concerned with promoting the cooperative economy (Société de development des coopératives - SDC). Implicitly, PQ political support for the Solidarity Fund was conditioned both by the party's concern to disentangle the provincial economy from Anglo-dominated finance, and by its need to incorporate a section of the labour movement in a context of austerity and a high level of class conflict. From the perspective of the union leadership, the Fund was always presented as a tool in the broader struggle for full employment, full employment being understood as the basis from 
which organized labour would be able to advance its longer-term goal of democratizing the economy (Le monde ouvrier, January 1984). There was no intention of using the Fund itself as a tool for the democratization of the workplace and the Solidarity Fund is not suited to this end (Morin, 2012). The intention, hardly less ambitious, was to take "collective responsibility for the employment problem" (Caron, n.d.), in response to the immediate demands of affiliated unions to save the furniture from the fire, and in assuming this responsibility regain a certain rapport de force with employers through traditional trade unionism. "If the capitalists don't want to put their money to work, then we will substitute for them" (interview subject \#4). The proposal to launch the Fund was formally adopted by the FTQ's 1983 annual congress, along with demands on the state to ensure full employment, measures to promote pay equity, and work time reduction with no loss of pay (FTQ’s Congress Report, 1983; FTQ’s Policy Statement, 1983).

The decision to go ahead with an investment fund was a contentious one within the FTQ and was condemned by the rival union central to its left, the CSN (Confédération des syndicats nationaux). The most effective support within the FTQ came from the United Steelworkers and the building trades, powerful affiliates that had been the most affected by plant closures and unemployment. Opposition was rooted in the public sector unions, the Canadian Union of Public Employees, as well as the organized left, which was strongly placed at the staff level within the FTQ (interview subject \#4,\#7). The left-right political distinction was not around full employment as the correct goal, but rather whether this was to be the sole responsibility of the state or whether the 'socio-economic partners' would share in this responsibility. Opponents argued from the congress floor that the project represented a break with class-struggle unionism and would place the FTQ in contradictory positions, both in the workplace vis-à-vis local unions, and at the political level, given the federations positions against tax-based subsidies to private capital. ${ }^{10}$ 
Adopted by 80 percent of congress participants (Le monde ouvrier, December 1983), the decision of the FTQ to go forward with an investment fund was a defeat for the left as it signalled a reversal of FTQ positions on this question and an acceptance of the new 'partnership' approach both at the political level and within the workplace (Gill, 1985; Piotte, 1998). Concern for maintaining employment came to trump improving wages and working conditions. A labour central that had formally adopted ten years previously a programme that heavily criticized public subsidies to private enterprise as a failed solution to unemployment, and that had called for a collective pooling of savings by the state to gain public control over the province's resource base, was now asking to become a partner with private enterprise with publicly-subsidized capital. ${ }^{11}$

\section{Investment strategy and social innovation}

The leadership of the FTQ has been at pains since the origins of the project to insist that the Fund would not just subsidize employment but would invest in profitable, growing enterprises with a view to making a profit. ${ }^{12}$ When the project was launched, investment opportunities arose as local unions pleaded with the employer to seek Fund financing as an alternative to mass layoffs or closing shop. In the course of the 1980s, the Fund began to shed its reputation among business owners as a union tool and employment rescue operation (interview subject \#3). Currently, the Fund is much more likely to receive investment requests from business owners and the Fund partners with other private equity investors and governmental development agencies in large industrial and infrastructure projects, a more 'proactive' approach that is forced on the Fund if it wishes to accumulate at the same rate as its competition. As the Fund has drifted from its original role and finds itself collaborating and competing with other investment funds, the question of what differentiates the fund as an employment creation tool and union vehicle is all the more relevant. There are three innovations in particular that merit discussion: the network 
of workplace representatives (réseau des responsables locaux, or RLs), the social audit (bilan social), and economic training (formation économique). We evaluate the Fund's investment practices insofar as they differ from less patient and anti-union forms of capital; the capacity of union members to direct investment decision-making through the RL network; and the social audit and economic training functions that accompany Fund investments.

\section{Investment strategy}

The principal goal of the Solidarity Fund remains employment creation. Since any investment in the real economy, including that of private institutional investors, banks or large corporations, can be said to create employment, there is little point in quantifying the number of jobs created by Solidarity Fund investments, and the Fund's annual reports have ceased to produce such figures. Investment is not the only factor that determines employment growth and it would be misleading to credit the Solidarity Fund with employment creation in private firms.

On the positive side of the ledger, there is little doubt that the Solidarity Fund, at least insofar as its active capital portfolio is concerned, meets the criteria of patient capital. The average investment horizon is 7 years, although the Fund does not maintain a policy on the matter. In cases of firm financial difficulty, the Fund will retain its investment and take an active role in workplace restructuring with a view to maintaining employment security, even if this means taking a hard line on wage demands. It disinvests when a window of opportunity presents itself - another buyer is interested, the firm goes public or is bought back by the owner. Before selling an ownership stake the Fund has an 'exit social audit' produced to ensure that disinvestment will not cause employment loss (interview subject \#6). Less than 10 percent of its active capital assets are rolled over annually on average. This lower level of investment turnover implies a lower profit rate than competing venture capital firms and a smaller number of annual investments than it otherwise might make if the Fund pursued a profit maximising strategy. ${ }^{13}$ 
The Fund does not exit in cases of poor short-term performance. Unlike private equity firms, the Solidarity Fund does not, with very rare exceptions, take majority positions in firms. Again, this is done to avoid situations in which the Fund would be expected to govern the enterprise in the interests of the workers or local union, if present (interview \# 3). ${ }^{14}$ Minority positions allow the Fund to take a pasive role in firm governance. The Fund is represented on firm boards by a lone accountant who meets with Fund staff in regular meetings and with union representatives as needed. To the very limited extent that the Fund exercises voice in firm governance, this is done not so much to increase financial return but to increase productivity and cooperative workplace relations, as discussed below through its 'social' innovations, all in the interests of maintaining employment. A reliance on economic training lessens recourse to external consultants which are likely to be anti-union and the Fund will rely on its extensive network in Quebec's SME sector to encourage its 'partner firms' to source from local suppliers and skilled labour (interview subject \#6).

Although figures are difficult to arrive at, it is estimated that Solidarity Fund capital costs slightly more - generally 3 to 5 percent more - than the competition (interview subject \#5). Solidarity Fund representatives make the argument to business owners that their contribution to cooperative workplace relations, through the economic training sessions, as well as the extensive knowledge they have built up on Quebec's leading economic sectors, makes this cost worth paying (interview subject \#6). Profit expectations, which vary by sector and risk level, are in the 15 - 17 percent range (interview subject \#5). At the same time, the Fund will invest in projects that offer a much lower profit expectation than private and even governmental agencies will accept, if there is a compelling social rationale to do so, and their patient capital orientation, including a concern to maintain employment levels, implies a lower rate on a number of investments. The Fund has earned an annual return of 6,8 percent over a five year period ending 
in 2016. For the purposes of comparison, Desjardins Capital, a leading competitor in Quebec's venture capital market, earned 3,8 percent. ${ }^{15}$

The Solidarity Fund is less reliant on financial return for asset accumulation for two specific reasons. Most importantly, generous tax incentives, over and above other Registered Retirement Savings Plan (RRSP)-eligible funds, ensure a high subscription rate. ${ }^{16}$ Beyond the tax-reduction incentive, workers are approached at work by their colleagues to contribute into the Fund for financial, retirement planning reasons and to support the local economy. The RLs are the only non-financial professionals allowed under law to do so. One implication for the capital market is that the Solidarity Fund can grow while underbidding its competitors and depress PE profit rates across the industry. ${ }^{17}$

On the negative side of the ledger, pressures on the Fund to meet profit expectations push it to make 'patient' capital investments that do not meet 'social' criteria or even contradict union positions. Two recent Fund investment projects are noteworthy. The first concerns a proposed $\$ 400$ million fund devoted to 'socio-infrastructures' - i.e. libraries, schools and community centers - on a private ownership model closely resembling private-public partnerships against which the Quebec section of the Canadian Union of Public Employees has strongly campaigned. The second concerns an investment in a Quebec corporation, Pangea, whose business model involves buying up agricultural land and leasing it back to tenant farmers (interview subject \#6; Le Devoir, April 21 2017). Neither project is motivated by advancing any social or union goal. P3s and land grabbing are long-term, high profit investments favoured by large pension funds in the context of low market returns and declining investment opportunities in the real economy. Retaining minority ownership positions protects the Fund from the expectations of workers and local unions that the Fund use its investments to intervene in firm governance to the benefit of local unions and workers. This rule does not protect the FTQ from damages to its 
reputation that may result from anti-union practices of its Fund's partner firms. The passive nature of Fund investment frees partner firms to consistently favour profit- and growth-oriented business strategies. The Fund does not oppose firms going public, for instance, and encourages internationalization (interview subject \#3) even if this dilutes any informal pro-labour influence the Fund may exert as partner firms become integrated into global finance and production networks. The dilemmas here were most publicly exposed by the Fund's investment in Montrealbased Gildan Activewear. The Fund had nurtured Gildan, a small Quebec textile firm, with a series of loans beginning in 1996 that allowed the company to relaunch as Gildan Activewear after having failed to raise funds from the big banks, which considered the project too risky (Batellier and Raufflet, 2007). The firm opened its first plant in Honduras in 1998 and went public on the Toronto (TSX) and New York (NYSE) exchanges that year. In 2002, now one of the largest producers of branded cotton t-shirts in North America, the company fired 38 workers for union activity at its El Progreso Honduras plant (Bérubé, 2003). After a media exposé, the Fund came under intense pressure to sell its highly profitable $11 \%$ stake in the company, which it proposed to do over a period of 24 months so as not to disrupt the share price (ibid.). The Fund finally finally divested its ownership of Gildan shares four years later, after they trippled in value from $\$ 18.16$ to $\$ 60.99$ on the TSX (Tison, 2007). That year Gildan closed its last two remaining plants in Quebec and transferred the entirety of its production to plants in Honduras, Nicaragua and Haiti (Desrosiers, 2007).

\section{Union control - the RL network}

Fund investment decisions are authorized by an executive board comprised of affiliated union representatives and independent members, currently in a majority, voted by Fund 
shareowners. Individual files are negotiated by investment professionals who are hired out of business schools and the banking industry. These latter have no particular commitment to the labour movement, are career motivated to make profitable investments and are liable to see the social and union commitments as fetters on their ability to close deals ("the only problem with the Fonds FTQ is the three letters after its name" is a running joke in the office, interview \#1). Fund managing directors, who do have union backgrounds, speak of having to use two sides of their brains simultaneously, the 'union' side and the 'financial' side.

The RL network is composed of volunteer representatives in unionized workplaces at a ratio of 1 non-staff rep for every 50 workers. The primary task of the RLs is to sell subscriptions to the Fund. The RL network was put in place out of necessity, that of convincing union members one on one to invest in the Fund in the absence of a collective vote for automatic pay check deductions. A virtue was made of this necessity as the RL network became the primary means by which rank-and-file trade unionists and union affiliates shape Fund investment policy - the RLs represent the "skeletal framework (l'ossature)" of the Fund and the founders credit this network with ensuring the success of the project and ensuring also that what would otherwise be a strictly financial instrument remains under the control of the labour movement (interview subject \#3, \#4). With 1,400 current members, the RLs represent the largest network of rank-and-file trade unionists within the FTQ. RLs volunteer out of commitment to union values and so these are 'shareholder activists' in an oddly literal sense of the term. They are concerned with the use of the Fund as a union lever, rather than with financial return, let alone maximising financial return.

Approximately 60 percent of Fund shares are owned by trade unionists. In order to maintain effective union influence over the Fund - in particular, to ensure that trade union representatives occupy a majority on the board - the FTQ must maintain and mobilize this network. Since Fund governance decisions turn on an exceptionally low voting participation rate, 
the mobilization of the RL network has been enough to ensure trade union control. The RLs are also convened at a local and regional level several times a year and receive paid work release for this purpose. These local and regional meetings are organized by Fund staff seconded from affiliated unions. Thus a link is established between the priorities and concerns of FTQ-affiliated unions and the Fund's effective voting base. Conflicts between Fund investment decisions and union priorities are raised in these meetings and pressure is exerted on Fund directors to intercede with employers in cases of union-management conflict. This is done on occasion through back channels.

The RL network must be considered a blunt instrument, since the RLs are not in a position to direct funds in any strategic way. At best, they function as a veto on investments that run counter to union principles or interests. "If the Fund took a decision against the interests of workers or with which we didn't agree, it would blow up quickly, very quickly" (interview subject \#7). ${ }^{18}$ The RL network is the primary means by which the Fund raises subscriptions. They "control the taps" and the Fund must take care to maintain its reputation among trade unionists for this reason. In 2017, CUPE was able to mobilize labour shareholders against the Fund's 'socio-infrastructure' proposal at the FTQ's annual congress. The motion was sent back to the Fund with requested revisions.

\section{The social audit}

The social audit refers to a report that is produced after a workplace visit and which is subsequently sent along with the financial report to the executive level prior to an investment being made in a prospective firm. A representative of the Fund meets with the human resource director, the local union leadership, where relevant, and informal groups of workers in the absence of management. The representative consults the collective agreement and the grievance file, looks at the turnover rate, evaluates the health and safety record, compares salaries to the 
industry and regional average, and compiles a demographic portrait of the workforce. As a part of this process, the Fund may in some cases put pressure on management and union leadership to sit down and resolve outstanding issues, especially grievances. The Fund will also prepare a list of recommendations to management and over a two to four week period work to improve workplace standards and practices, all prior to an investment decision being made. Arguments in favour of improving health and safety, communication and morale are couched in terms of productivity and economic performance so as to be more palatable to business owners. Fund representatives tread gingerly as they know that firm owners can very well get financing from less demanding sources. In some cases, the social audit establishes a benchmark for return visits (interview subject \# 4, $\# 5$ ). If the industry average wage is $\$ 25 / \mathrm{hr}$., the Fund will not invest in a company that is paying $\$ 12$ (interview subject \#6). Beyond these workplace-level considerations, the social audit considers whether an investment in a non-union firm will increase competitive pressures on a unionized firm ("We are not going to rob Peter to pay Paul”). The Fund does not have a policy of generally favouring a unionized over a non-unionized firm, or an FTQ-unionized firm over one organized by its rival.

The social audit was an afterthought. It was put in place to prevent the Fund from finding itself in an impossible situation where its reputation among both workers and businesses owners would suffer from an investment. There is also a financial risk interest in screening out certain firms for 'social' considerations, especially poor labour relations. The social audit represents one attempt at responding to the contradiction at the heart of the project: how can an investor be a partner in management while also being responsible to the labour movement? This contradiction emerged in one of the Fund's first forays, an investment in a supplier to Texaco that had been recently unionized against the strong opposition of the owner. The owner expected the Fund to intervene in his favour, to reduce workplace conflict and discipline the union's wage demands in 
difficult first contract negotiations. The local union leadership expected the exact opposite of their Solidarity Fund and it was in this expectation that they had requested the investment (Caron, n.d.). From the Fund's perspective, the problem was simply that the workers did not want to save their jobs and had little interest in partnering with management to improve matters. In avoiding contentious work sites, the social audit protects the Fund from finding itself called on to favour either workers or their business partners, either of which course of action would pose considerable risk to the reputation it wished to create, that of being neither a management tool nor a Trojan horse for labour (interview subject \#4). If the grievance file is too long and if the workers themselves do not wish for the Fund to take an ownership position, the Fund does not invest. The social audit is intended to identify such cases. The financial report represents the Fund's first 'insurance policy' against a bad investment. The social audit, along with the lines of communication this opens up between plant workers and the Fund, is a second insurance policy (interview subject \#3).

The social audit does not of course ensure that firms respond to union principles or rules once an investment has been made. The Fund has at times found itself an investor in firms that are actively engaged in undermining union standards and employment. Perhaps the most aggravating such case was the lock-out and ultimate defeat of the Vidéotron cable workers in 2002-2003, a major turning point in industrial relations in the province (Rouillard, 2004). Vidéotron management precipitated the conflict by demanding the right to outsource a portion of the work of the bargaining unit, represented by the FTQ-affiliated Canadian Union of Public Employees (CUPE). Vidéotron had purchased the unit with financing from the Caisse de placement et dépot (CPD), the province's largest pension fund, with a view to promoting the Quebec-based company against Vidéotron's larger, Toronto-based rival in the context of industry consolidation. Immediately following the lock-out and for the duration of the work stoppage, the 
company maintained operations by outsourcing the work to Entourage, a small unionized firm that the Solidarity Fund had created in 1996 to save the jobs of cable workers at risk in a previous wave of outsourcing, but at wages below union scale. Essentially scabbing on the Vidéotron strike, low-cost Entourage allowed Vidéotron to whipsaw its unionized workforce, ultimately gaining more in concessions than what it would have saved in outsourcing. ${ }^{19}$ Neither a union ownership stake in Entourage nor union representation on the board of the CDP provided any leverage to the local workforce in this bruising fight.

\section{Economic training}

As a rule, the Solidarity Fund does not intervene in firm-level labour relations. The local union leadership does not want the Fund to meddle in its defined area of responsibility for fear that it may undermine its authority, and the Fund does not wish to find itself at cross purposes between local labour leadership and its business partners. The most significant exception to this rule are Solidarity Fund-organized economic training sessions.

The Fund employs a team of 9-10 popular educators whose role is to give workers an understanding of basic accounting concepts and principles. This ensures that workers have the tools required for going over the company's financial statements. These statements have been independently audited by the Fund and accountants responsible to both the firm and the Fund are present during these sessions as a check on the veracity of the information. In addition to this, the educator will convene groups of employees to discuss labour process issues at which workers are asked to give their input on how to achieve efficiencies in operations. The owner is invited at the end of the process to present the business plan. If requested, the Fund will animate workgroups formed by plant managers, workers and union representatives to resolve work organization-level conflicts (interview subject \#6). Sessions are organized at the request usually of the human resources director or, more rarely, the local union. They take place normally over a 2 day period 
and are organized both onsite and off. Since 1989, tens of thousands of workers in Quebec have gone through these training sessions.

The reference to economic training was inserted in the Fund's enabling legislation to give it a more 'social' profile, beyond its role in simply saving or generating employment, and thus ease its acceptance within the ranks of the FTQ (interview subject \#4). As with the social audit, the much more significant workplace education sessions emerged as a means of managing the liabilities inherent to the Fund's contradictory position between local labour and firm ownership, although founders were also inspired by the possibility of "raising the consciousness level" and transferring information to workers in order to empower them (ibid.).

The education sessions studiously avoid labour relations. But access to the books and the discussions that arise from this information cannot but have an impact on the bargaining process. "The first thing that workers do once the financial information has been verified, once the training has been done, is they figure out what impact their salary demands will have on the gross profit rate (interview subject \#4)." This takes a lot of the art and politics - not to mention time out of the bargaining process, and this was not appreciated by local labour leadership. Indeed, resistance to institutionalizing the training and open book sessions came from the union side, not from management.

Discussions around labour process and other operational questions also arise naturally from being granted access to the books. Workers themselves are not naïve about these sessions. Solidarity Fund educators report that they are perceived at worksites as representing a shareholder interest, not a union one (interview subject \#1). They see the cost of materials and energy inputs and are motivated to find ways of reducing these to free up value for their wage demands. "People began to understand that a part of their power in the plant was, if the rules were well established, that they could create value in better controlling their work environment" 
(interview subject \#4). This can have a salutary effect, from an upper management or ownership perspective, on profits as well as work culture (line managers chafe at these sessions because their rules and practices are often found at fault by workers for undermining efficiency). These perhaps unintended effects of the training sessions on profit rates and partnership-oriented work culture explain their "explosive" success within the business community (Ibid). The Fund is regularly approached by business owners to conduct economic training sessions even in the absence of the Fund considering an ownership stake. It remains a significant part of the "valueadded' that the Solidarity Fund uses to distinguish itself from its rivals on the province's capital market (interview subject \#6). The training sessions used to be offered free of charge, but a fee for service model was introduced in 2013 as a result of pressure to bring the cost of Fund capital in line with its competitors (interview subject \#1).

The 'social' dimension to the Fund should not be counterposed to the financial or simply coded as efforts to extend union control over capital. As we have seen, these three social innovations also serve a clearly defined financial interest, both in controlling for risk and through their economic performance effects on firms. At the same time, the 'social' refers to the innovations the Fund has used to manage the contradictions of being a labour investor. The social audit screens out the most conflictive workplaces, workplace conflict resolution is encouraged within the process of the social audit, and again much more significantly with the economic training sessions which take much of the heat out of plant-level collective bargaining. These two concerns - the financial stake and the management of liabilities - are reconcilable to a degree. To the extent that the Solidarity Fund intervenes in labour relations, it mediates between firm owners and employees by working hard to reduce workplace conflict with the goal of increasing productivity, financial return, and employment security. 


\section{Conclusion}

The Solidarity Fund is an outlier in the realm of 'managing workers' capital'. We know of no other case in which unions exert such a degree of control over the investment of workers' savings, or of influence in the firm governance and workplace relations in the guise of investors. Not only are there very few limits, of either a legislative or judicial nature, imposed on Fund investment strategy, the Fund is given significant public support in reconciling union and financial interests. It is a most likely case of unions extending financial leverage over firms to advance workers interests, be they employment stability, improving labour standards or furthering worker and local union power. If increased union control over capital markets and firm-finance relations could be used to advance these goals, we would expect to the Solidarity Fund to succeed in doing so.

Our findings, summarized in Table 1, are mixed but mostly negative on this score. The ability to direct investment flows does not overcome the contradictions that are inherent in using financial levers to advance workers power in the workplace. Even in the most advantageous context of the Solidarity Fund, with its generous tax advantages and permissive enabling legislation, these contradictions are imposed by the competitive nature of capitalism. Like the genie released from its bottle, capital imposes its own goals - profit and accumulation - on those who would direct it for their own purposes. The Fund may improve workplace standards in cases where this does not conflict with competitive practices, and the Fund will attempt to block form of industrial restructuring that supress collective bargaining. But Fund investment in a firm does not strengthen local union power or prevent firms in which the Solidarity Fund maintains a minority ownership stake from making commercial decisions that run counter to workers' 
interests. To the limited extent to which the Fund intervenes to mediate and resolve conflict outside the bounds of the employer relationship, it may just as well undermine local union authority and militancy. It is noteworthy that local labour leaderships do not wish for the Fund to intervene in labour relations and the founders of the Fund themselves were keen to avoid doing so for the same reason: that the Fund would act to protect its investments at the expense of local union autonomy, which Fund leadership themselves recognized as necessary to defend workers' interests at the workplace level.

The founders of the Solidarity Fund understood the limits and liabilities involved in attempts to use investment in furtherance of union goals, and in the practical work of managing these contradictions introduced institutional practices and rules to manage these. As we have shown in this paper, the social audit and economic training aspects of the Fund, while giving it something of a 'social' profile, are best understood as attempts to temper the contradictory expectations that local workers and business owners had of a labour investor. These tools are taken seriously and have real, if limited, effects on the employment relationship. They are oriented towards reducing conflictual workplace relations and promoting productivity in the interests of furthering employment stability, not advancing union power.

Our findings are more positive insofar as the Fund represents a form of patient capital that grants firms subsidized access to credit. The Solidarity Fund was the first venture capital investor in Quebec and remains the most significant source of external financing for small and medium sized businesses in the province. Along with other government-supported forms of development capital, the Solidarity Fund plays an important role in maintaining a more coordinated, patient form of firm-finance relations that still characterizes Quebec's political economy. It occupies a position that would otherwise be assumed by much more aggressive, profit-maximising funds or the Toronto stock market, with everything that this entails for the transfer of risk to firms and 
workers. In this limited sense then, the Solidarity Fund has attenuated some of the pressures that have been responsible for undermining union power across North America. By making available a more committed form of firm financing, the Solidarity Fund allows firms to engage in more cooperative work and employment practices, including collective bargaining, while sustaining competitive positions in North American markets. However, as the Gildan and Vidéotron cases demontrate, passive capital investment strategies do not prevent the Fund from finding itself in partnership with firms whose business strategies run counter to basic union principles, including freedom of association and strike solidarity.

From this case, we consider it unlikely that increased control over union pension funds could accomplish what proponents of the 'managing workers capital' approach expect of such control. Stepping into the world of finance can be perceived as an enlargement of union repertoires, but for labour, the limits to what can be accomplished are imposed by the nature of contradictory social relations under capitalism. Exerting agency in the form of an investor appears to enlarge the sphere of action of the labour movement when labour is at best taking responsibility for outcomes that it cannot control. By assuming this responsibility - for full employment, for better regulated capital markets and better labour standards - the labour movement is tacitly absolving the state of responsibilities that organized workers used to demand of it. These responsibilities have become diffused and now burden those who are most driven to find what would seem to be practical solutions. By delegating responsibility for positive employment outcomes to labour investors, without also creating the power to effectively control markets or firm decision making, unions are forced to internalize a contradiction between two opposed logics: the struggle of workers to defend themselves at work against the constant pressure from capital to rationalize their labour, reduce its costs, and increase its intensity. Labour unions must negotiate a compromise between these two logics. But in the Solidarity Fund we 
have a further compromise in that a labour institution imposes this logic on itself, and in so doing grants it legitimacy.

Those who argue for increased union control over workers' savings should be careful what they wish for (even if they are unlikely to get it). The Solidarity Fund should not be taken as a goal or model. It should be understood in its proper historical context as a fall-back position that, rather than pointing to a future of full employment, economic transformation, and the democratization of the workplace, led rather in the direction of firm-level productivity pacts and competitiveness-oriented collective bargaining. The advent of the Solidarity Fund was consistent with, and furthered, a larger ongoing shift towards a corporatist and partnership-oriented trade unionism in Quebec, as union critics at the time feared that it would. Though the Solidarity Fund may be unique, this shift towards labour's acceptance of neoliberal capitalism as the horizon of the possible is far from unique (MacDonald, 2014). As far as Quebec is concerned, the repressed historical alternative against which the Solidarity Fund could be evaluated would be state-led industrial policy, the socialization of finance and work time reduction, positions that all the major labour centrals held up until the early 1980s. In our view, these positions remain just as relevant in the current context of financialized capitalism, ecological crisis and the technological displacement of work. 


\section{Table 1: Summary of main findings}

Solidarity Fund practices
How do these practices respond to the institutional needs of the Fund as a labour investor?
How do these practices potentially enable local union power over employers?

RL network
Economic training
-information
sharing
-high-performance
workplace
orientation

Social audit

Tax incentives

Passive capital investment strategies -minority ownership rule

-long-term orientation -pro-employment restructuring

-confers a fund raising advantage over competing funds -maintains union control -checks internal Fund tendency to privilege financial returns over union values

-helped overcome initial opposition

within unions

-gives the Fund a more 'social' profile -disciplines wage expectations in partner firms

-lessens the liability and cost of labour-sponsored investment for firms

-intended to protect the Fund from investing in workplaces that may tarnish its image

(Texaco)

-allow the Fund to accumulate without pursuing profit maximization -distinguishes the Fund from more aggressive and risk-averse financial actors

-protects the Fund from expectations that it exert union leverage over firms

-rationalizes tax advantages -subsidized capital stabilizes employment levels

-grants union access to the proprietary financial information and insight into business strategy

-not significant

-protects unionized firms from profit-maximizing funds and pressures from

-blocks recourse to antiunion consultants, practices financial markets
Limits and contradictions of these practices for local unions and the labour movement

-not significant -undermines the authority of local union bargaining committees -furthers competitivenessoriented bargaining and plant-level partnership -not significant -increases dependence on government policy -confers union legitimacy on subsidies to private capital and private pensions -undermines the tax base -no investment preference for unionized workplaces -passive capital investments can run counter to labour movement positions (P3s) -allows firms to engage in anti-union practices (Gildan)

-confers union legitimacy on concession bargaining -restructured low cost firms increases competitive pressures on union firms (Entourage) 


\section{Works Cited}

Abowd JM (1989) The effect of wage bargains on the stock market value of the firm. The American Economic Review, 70(4): 774-800.

Archer S (2011) Pension Funds as Owners and Financial Intermediaries: A Review of Recent Canadian Experience. Available at: $\underline{\text { https://ssrn.com/abstract }=1884441}$

Auvray T, Dallery T, Rigot S (2016) L'entreprise liquidée. La finance contre l'investissement. Paris: Michalon.

Appelbaum E, Batt R (2014) Private Equity at Work: When Wall Street Manages Main Street. New York: Russell Sage Foundation.

Appelbaum E, Batt R, Clark I (2013) Implications of financial capitalism for employment relations research: evidence from breach of trust and implicit contracts in private equity buyouts. British Journal of Industrial Relations, 51(3): 498-518.

Baker D, Fung A (2001) Collateral Damage: Do Pension Fund Investments Hurt Workers? In: Fung A, Hebb T, Rogers J (eds) Working Capital: The Power of Labor's Pensions, Ithaca, NY: Cornell University Press, 13-43.

Barber R (1982) Pension funds in the United States issues of investment and control. Economic and Industrial Democracy, 3(1): 31-73.

Bauer R, Koedijk K, Otten R (2005) International evidence on ethical mutual fund performance and investment style. Journal of Banking \& Finance, 29(7): 1751-1767.

Batellier P, Raufflet E mimeo. Le Fonds de solidarité de la FTQ et le dossier Gildan. Available at: $\underline{w w}$.aderse.org.

Becker, BE, Olson CA (1989) Unionization and shareholder interests. ILR Review, 42(2): 246261.

Bérubé G (2003) L'entreprise a fait des gestes antisyndicaux - Le Fonds FTQ se retire de Gildan. Le Devoir, November 13.

Bouw B (2016) Federal tax credit sparks renewed interest in labour-sponsored venture funds. The Globe and Mail, April 28.

Calvert J (2005) Pensions and public-private partnerships: A cautionary note for union trustees. Just Labour, 5: 1-13.

Carberry EJ (2011) Employee ownership and shared capitalism: Assessing the experience, research, and policy implications. In: Carberry E.J (ed) Employee Ownership and Shared Capitalism: New Directions in Research. Champaign, IL: Labor and Employment Relations Association, 1-26. 
Carmichael I (2006) Pension Power: Unions, Pension funds, and Social Investment in Canada. Toronto: University of Toronto Press.

Carmichael I, Quarter J (2003) Money on the Line: Workers' Capital in Canada. Ottawa: Canadian Centre for Policy Alternatives.

Caron N. n.d. Une démarche pédagogique axée sur la responsabilisation. mimeo.

Clark G, Hebb T (2004) Pension fund corporate engagement: The fifth stage of capitalism. Relations industrielles/Industrial relations, 59(1): 142-171.

Coiquaud U, Morissette L (2010) Penser le renouveau syndical par la sphère financière. Relations Industrielles/Industrial Relations, 65(2): 196-214.

Comeau Y, Lévesque B (1993) Workers' financial participation in the property of enterprises in Québec. Economic and Industrial Democracy, 14(2): 233-250.

Cumming DJ, MacIntosh JG (2006) Crowding Out Private Equity: Canadian Evidence. Journal of Business Venturing 21(5): 569-609.

Cumming DJ, MacIntosh JG (2007) Mutual funds that invest in private equity? An analysis of labour-sponsored investment funds. Cambridge Journal of Economics, 31(3): 445-487.

Deeg R, Hardie I (2016) What is patient capital and who supplies it? Socio-Economic Review, 14(4): 627-645.

Della Croce R, Kaminker C, Stewart F (2011) The role of pension funds in financing green growth initiatives. OECD Working Papers on Finance, Insurance and Private Pensions, 10: $1-70$.

Desrosiers E (2007). Gildan ferme ses deux dernières usines au Canada. Le Devoir, March 28.

Dubuc P (n.d.) Bell et Quebecor s'entendent... contre leurs travailleurs. L'autjournal.

Estevez-Abe M, Iversen T, Soskice D (2001) Social protection and the formation of skills: a reinterpretation of the welfare state. In: Hall P, Soskice D (eds) Varieties of Capitalism: The Institutional Foundations of Comparative Advantage. Oxford: Oxford University Press, 145-183.

Fonds FTQ (2017). Financial Statements as of November 30 2017. Available at: http://www.fondsftq.com/en/a-propos/donnees-financieres.aspx

Fung A, Hebb T, Roger J (eds) (2001) Working Capital: The Power of Labor's Pensions. Ithaca, NY: Cornell University Press.

Gill L (1985) Partenariat Social et Actionnariat Ouvrier: Du rachat D'entreprises aux "Fonds de Solidarité". J-M Tremblay: Les classiques des sciences sociales. 
Ghilarducci T, Hawley J, Andrew W. (1997) Labour's Paradoxical Interests and the Evolution of Corporate Finance. Journal of Law and Society, 24(1): 26-43.

Gindin S (1988). "Playing a capital game: The Quebec Solidarity Fund". Our Times magazine, March, p.24-25.

Hall P, Soskice D (eds.) (2001) Varieties of Capitalism: The Institutional Foundations of Comparative Advantage. Oxford: Oxford University Press.

Hebb T (2001) The challenge of labor's capital strategy. Social Policy, 31(3): 38-38.

Jacoby S. (2008) Finance and labor: Perspectives on risk, inequality, and democracy. In: Brown C, Eichengreen B, Reich M (eds) Labor in the Era of Globalization. Cambridge: Cambridge University Press, 94-150.

Knafo S, Dutta SJ (2016) Patient capital in the age of financialized managerialism. SocioEconomic Review, 14(4): 771-788.

Kruse DL, Blasi JR, Park, R. (2010). Shared capitalism in the US economy. Shared Capitalism at Work, 41.

Laliberte P (1997) Agency problems in the capital markets and the employment relationship: The possibility of efficiency-enhancing institutional innovation: An empirical case-study. Unpublished doctoral thesis, University of Massachussetts Amherst, Amherst.

Lazonick W, O'sullivan M (2000) Maximizing shareholder value: a new ideology for corporate governance. Economy and society, 29(1): 13-35.

Lévesque C, Murray G (2010) Understanding union power: resources and capabilities for renewing union capacity. Transfer, 16(8): 333-350.

Lincoln A (2000) Working for regional development? The case of Canadian labour-sponsored investment funds. Regional Studies, 34 (8): 727-737.

Marens R (2004) Waiting for the North to rise: Revisiting Barber and Rifkin after a generation of union financial activism in the US. Journal of Business Ethics, 52(1): 109-123.

MacDonald IT (2014) Towards neoliberal trade unionism: Decline, renewal and transformation in North American labour movements. British Journal of Industrial Relations, 52(4): 725752 .

McCarthy M (2014) Turning labor into capital: Pension funds and the corporate control of finance. Politics \& Society, 42(4): 455-487.

McCarthy M (2017) Dismantling Solidarity: Capitalist Politics and American Pensions Since the New Deal. Ithaca: Cornell University Press.

Morin P (2012) The Fonds de Solidarite: Historical and political foundations, what lessons for economic democracy? Review of Radical Political Economics, 44(1): 82-99. 
Naczyk M (2016) Creating French-style pension funds: Business, labour and the battle over patient capital. Journal of European Social Policy, 26(3): 205-218.

Peters J. The rise of finance and the decline of organised labour in the advanced capitalist countries. New Political Economy, 16(1): 73-99.

Piotte J-M (1998) Du Combat au Partenariat: Interventions Critiques sur le Syndicalisme Québécois. Québec: Éditions Nota bene.

Rettino-Parazelli K (2017) L’UPA furieuse de voir «l'argent des Québécois» investi dans Pangea. Le Devoir, April 21.

Rouillard J (2004) Le Syndicalisme Québécois. Montréal: Boréal.

Rifkin J, Barber R (1978) The North Will Rise Again. Boston: Beacon Press.

Soederberg S (2009) Corporate Power and Ownership in Contemporary Capitalism: The Politics of Resistance and Domination. New York: Routledge.

Stanford J (1999) Paper Boom. Toronto: Lorimer.

Talbot L (2013) Why shareholders shouldn't vote: A marxist-progressive critique of shareholder empowerment. The Modern Law Review, 76(5): 791-816.

Tison M (2007) Le Fonds FTQ encore actionnaire de Gildan. La Presse, February 2.

Webber DH (2014) The use and abuse of labor's capital. New York University Law Review, 89(6): 2106-2189.

Webber DH (2018) The Rise of the Working-Class Shareholder: Labor's Last Best Weapon. Cambridge: Harvard University Press.

Weststar J, Verma A (2007) What makes for effective labor representation on pension boards? Labor Studies Journal, 32 (4): 382-410.

Wessel PJ (1986) Job creation for union members through pension fund investment. Buffalo Law Review, 35(1): 323-364.

Wright EO (2010) Envisioning Real Utopias. London: Verso.

\section{Archival materials}

Fédération des travailleurs et des travailleuses du Québec (1983). Congress Report.

Fédération des travailleurs et des travailleuses du Québec (several dates). Le monde ouvrier. 
Fédération des travailleurs et des travailleuses du Québec (1983). Policy Statement.

\section{NOTES}

1 The authors wish to acknowledge the financial support of the Université de Montréal and the research assistance of Audrey Laurin-Lamothe and Komi Viagbo.

${ }^{2}$ Fund governance was reformed in 2013-2014 as a pro-active response to a public investigation into corruption in the construction industry. Prior to this reform, the FTQ controled a majority of seats on the board of directors, which approves all investment decisions, and the president of the FTQ also presided over the board of the Fund. Today, an independent president directs the board and a majority of the seats are now occupied by 'independent' members voted by Fund investors. In practice, the labour central is able to maintain control by fielding union-endorsed candidates and campaigning on their behalf.

${ }^{3}$ Wording from the Solidarity Fund website, accessed December 18, 2017 at [https://www.fondsftq.com/fr-ca/a-propos/qui-sommes-nous.aspx]

${ }^{4}$ Attempts to replicate the financial success of the Solidarity Fund in English Canada have been disapointing and supportive government subsidies have been discontinued in Ontario and Manitoba. Poor financial outcomes are largely due to a lack of union involvement and poor regulatory design. As Cummings and MacIntosh (2007: 483-484) have noted, "Labour unions do not play a monitoring role in LSIF governance, and merely rent their name to the fund. LSIF managers have been able to charge fees that give rise to MERs in excess of 4\%, in contrast to the average MER for all Canadian mutual funds of $2.29 \%$... Investors in LSIFs similarly play no role in the governance of the funds, as the tax incentives provided have led investors to contribute \$Can 10 billion to the LSIFs despite poor fund performance, excessive MERs and misuse of capital."

${ }^{5}$ The Solidarity Fund holds 35 percent of its assets in a market index fund and aligns its voting in shareholder assemblies with 'socially responsible' investment associations such as SHARE and the Committee for Workers Capital, sponsored by global union federations. However, it does so with a view to managing reputational risk rather than any serious attempt to shape labour practices (interview \#7). "Unfortunately, looking at the overall record, it is difficult to claim that these efforts have done a great deal for organized labor in the United States" (Marens, 2004:

117).

${ }^{6}$ This concern has given rise to various attempts at identifying what might constitute patient capital. Deeg and Hardie (2016) have proposed a typology of 'varieties of capital' based on three criteria: investment horizon (long versus short), whether or not the investor uses voice in firm governance to increase short term performance, and the likeliness of the investor to exit for reasons of poor short term performance.

${ }^{7}$ Municipal union participation in the bailout of New York City in the mid 1970s is a pregnant example, as is the Steelworkers partnership with private equity financier Wilbur Ross in the rationalization of the US steel industry in the early 2000s (see MacDonald, 2014).

${ }^{8}$ In 2013, the Conservative federal government began reducing the federal tax incendive with a view to phasing it out entirely by 2017 . The Liberal government of Justin Trudeau reversed course after lobbying efforts by the FTQ (Bouw, 2016). 
${ }^{9}$ Ironically enough the Solidarity Fund bears a striking resemblance to the counter-proposal of the Swedish Employers Association to the Meidner wage earner funds in that contributions are voluntary, assets are invididually owned, and there is no intention of gaining majority ownership and control. We are indebted to Komi Viagbo for this point.

10 "Les interventions du Fonds de solidarité pourraient placer la FTQ en situation contradictoire quant aux choix des entreprises (ex. armaments), quant aux attitudes patronales de telles entreprises où nous serions ainsi impliquées, mais sans contrôle (ex. respect de la Loi sur le salaire minimum) ou encore quant aux revendications des travailleurs en négociation de telles entreprises ed difficulté et dépannées par le Fonds."

Resolution 103 proposed by SCFP (CUPE) local 313.

${ }^{11}$ The document was a collective effort of FTQ staff (lead author André Leclerc) titled ' $L$ 'État rouage de notre exploitation', whose literal translation is 'The state : cog in the wheel of our exploitation'. It was formally adopted by the 1971 Congress of the FTQ.

12 "Le président de la FTQ souligne que 'le Fonds de solidarité est d'abord un outil de lutte pour le plein emploi qui demeure notre objectif principal.' Il ajoute que c'est un moyen additionnel de 'changer les règles du jeu, par des réformes progressives,' sur la voie de la démocratie économique et du socialisme démocratique. 'Le plein emploi est le seul objectif acceptable pour une société qui aspire à la social-démocratie."” (Fournier, 1991: 59).

${ }^{13}$ To take a representative year (2015), the Solidarity Fund accounted for 17 percent of venture capital fund transactions and 25 percent of total value of PE investment in the province. Canadian Venture and Private Equity Association, 2015.

14 “On excluait pas la possibilité d'en prendre le contrôle majoritaire si c'est pour une réorganisation que le propriétaire n'ai plus les moyens de suivre mais c'est transitoire, on ne contrôlerait pas l'entreprise, on ne le trouve pas nécessaire. C'est pas notre job, on ne veut pas. Personne non plus, notre rôle de syndicaliste, c'est défendre les travailleurs, les intérêts des travailleurs menacés par la menace de l'emploi."

${ }^{15}$ Figures from respective annual fund reports.

${ }^{16}$ Fund publicity gives a representative example: assuming a $\$ 47,000$ annual gross salary, a \$1000 purchase of Solidarity Fund shares costs as little as \$329 after RRSP tax rebates. Accessed on May 19, 2017 at https://www.fondsftq.com/en/reer/pourquoi-choisir-le-fonds/comparer-lereer-du-fonds.aspx . Tax incentives over and above RRSP rates are capped at a $\$ 5000$ purchase.

17 The Solidarity Fund's tax incentives periodically come under political pressure from the banks for this reason. Cummings and MacIntosh $(2006,2007)$ find that tax subsidies to laboursponsored investors have allowed them to outbid their competitors, depressing profit rates and crowding out other forms of private equity in Canada, including Quebec. If we look at the Quebec capital market itself, there is no prima facie evidence that the strong presence of government-backed venture capital and the Solidarity Fund in particular have reduced the overall supply of venture capital. Indeed, Quebec's venture capital market is among the best capitalized among OECD countries. Venture capital investments over the period 2011-2013 represent 0.24 of Quebec's GDP, above New York (0.21), Texas (0.21) and Ontario (0.17), although significantly below California (0.83) and Massachusetts (0.83) (Quebec Institute of Statistics, 2014). Compared with these North American jurisdictions, the venture capital market in Quebec is more oriented to late stage, more mature firms which would otherwise seek financing on the open market (Ibid.). 
${ }^{18}$ Indeed, when in 2017 the Solidarity Fund proposed investing in PPPs - billed as long term investment in socially necessary infrastructure - the project was defeated in Congress by CUPE and sent back to the drawing board.

19 "La vente des techniciens à Entourage devait rapporter 15 millions par année, mais les concessions consenties par les syndiqués ont permis d'obtenir advantage" (Vidéotron representative Luc Lavoie, cited in Dubuc, n.d.) 